\title{
Chronic arthritis and cardiovascular disease: Altered blood parameters give rise to a prothrombotic propensity
}

Citation for published version (APA):

Beinsberger, J., Heemskerk, J. W. M., \& Cosemans, J. M. E. M. (2014). Chronic arthritis and cardiovascular disease: Altered blood parameters give rise to a prothrombotic propensity. Seminars in Arthritis and Rheumatism, 44(3), 345-352. https://doi.org/10.1016/j.semarthrit.2014.06.006

Document status and date:

Published: 01/12/2014

DOI:

10.1016/j.semarthrit.2014.06.006

Document Version:

Publisher's PDF, also known as Version of record

\section{Document license:}

Taverne

Please check the document version of this publication:

- A submitted manuscript is the version of the article upon submission and before peer-review. There can be important differences between the submitted version and the official published version of record.

People interested in the research are advised to contact the author for the final version of the publication, or visit the DOI to the publisher's website.

- The final author version and the galley proof are versions of the publication after peer review.

- The final published version features the final layout of the paper including the volume, issue and page numbers.

Link to publication

\footnotetext{
General rights rights.

- You may freely distribute the URL identifying the publication in the public portal. please follow below link for the End User Agreement:

www.umlib.nl/taverne-license

Take down policy

If you believe that this document breaches copyright please contact us at:

repository@maastrichtuniversity.nl

providing details and we will investigate your claim.
}

Copyright and moral rights for the publications made accessible in the public portal are retained by the authors and/or other copyright owners and it is a condition of accessing publications that users recognise and abide by the legal requirements associated with these

- Users may download and print one copy of any publication from the public portal for the purpose of private study or research.

- You may not further distribute the material or use it for any profit-making activity or commercial gain

If the publication is distributed under the terms of Article $25 \mathrm{fa}$ of the Dutch Copyright Act, indicated by the "Taverne" license above, 


\title{
Chronic arthritis and cardiovascular disease: Altered blood parameters give rise to a prothrombotic propensity
}

\author{
Jilke Beinsberger, MSc, Johan W.M. Heemskerk, PhD, Judith M.E.M. Cosemans, PhD* \\ Department of Biochemistry, Cardiovascular Research Institute Maastricht (CARIM), Maastricht University, P.O. Box 616, 6200 MD Maastricht, \\ the Netherlands
}

\section{A R T I C L E I N F O}

Keywords:

Rheumatoid arthritis

Ankylosing spondylitis

Psoriatic arthritis

Platelets

Coagulation

Cardiovascular disease

TNF- $\alpha$

\begin{abstract}
A B S T R A C T
Objective: Rheumatoid arthritis, and to a lesser extent ankylosing spondylitis and psoriatic arthritis, associates with increased morbidity and mortality due to cardiovascular complications. We hypothesized that the increased risk of cardiovascular disease is reflected by changes in blood parameters that are compatible with a prothrombotic propensity. To substantiate this notion, we performed an extensive literature search identifying such parameters.

Methods: A search through PubMed (1970-2013) was done to find primary articles with the following search terms: rheumatoid arthritis, ankylosing spondylitis, psoriatic arthritis or synovial fluid. These were combined with keywords reflecting processes of atherothrombosis: atherosclerosis, cardiovascular disease, coagulation, endothelial, fibrinolysis, mean platelet volume, microparticle, platelet, platelet count and mass, thrombosis, and thrombus.

Results: The published studies point to a multitude of blood-related processes that can contribute to a prothrombotic propensity in chronic inflammatory diseases. These include an increase in platelet mass; low-level platelet activation, enforced by interaction with leukocytes and the formation of proinflammatory cytokines; a locally activated endothelium; and an increased coagulant activity. Patient treatment with methotrexate or TNF- $\alpha$ blockers appears to result in normalization of several of these prothrombotic parameters.

Conclusion: This analysis provides a first identification of the mechanisms by which inflammatory arthritis can aggravate cardiovascular disease.
\end{abstract}

(c) 2014 Elsevier Inc. All rights reserved.

\section{Introduction}

Chronic inflammatory arthritides like rheumatic and spondyloarthritis are differentiated through their clinical manifestations, but they have in common disabling inflammatory symptoms of the joints. The treatment options for these diseases are partly different and rely on the efficacy of disease-modifying drugs to suppress radiographic changes and specific clinical manifestations. On the other hand, all forms of chronic arthritis are associated with an increased risk of cardiovascular disease [1]. Furthermore, metaanalyses reveal that patients with rheumatic arthritis (RA) may have a $50 \%$ increase in mortality due to cardiovascular disease, while patients with spondyloarthritis, either ankylosing spondylitis (AS) or psoriatic arthritis (PsA), display a $25-40 \%$ higher mortality as a consequence of cardiovascular complications [2,3].

\footnotetext{
This work was supported by Grants from the Center for Translational Molecular Medicine (INCOAG) to J.W.M.H. and J.M.E.M.C.; the Netherlands Heart Foundation (2011T6) to J.M.E.M.C.; and ZonMW (MKMD 114021004) to J.W.M.H. and J.M.E.M.C. * Corresponding author.

E-mail address: judith.cosemans@maastrichtuniversity.nl (J.M.E.M. Cosemans).
}

This insight has prompted the American College for Rheumatology and the European League Against Rheumatism (ACR/EULAR) to issue specific recommendations for cardiovascular risk management in patients with inflammatory arthritis [4]. The prevalence of cardiovascular disease in these patient groups is no more than partly explained by the classical Framingham risk factors, i.e., male sex, age, systolic blood pressure, smoking, diabetes mellitus, plasma cholesterol, and body mass index [5]. This suggests that other likely blood-related disease factors contribute to the prothrombotic propensity.

For this article, we hypothesized that the higher risk of cardiovascular disease in patients with chronic inflammation of the joints is reflected by changes in blood parameters that are compatible with a prothrombotic propensity. To confirm this, we searched the published literature on relevant changes in blood-related parameters in patients with RA, AS, or PsA, categorized in changes in platelet activation, leukocyte function, endothelial activation, coagulation, and fibrinolysis. From this analysis, we deduced potential mechanisms on how these changes in blood parameters can link chronic arthritis to cardiovascular disease. 


\section{Methods}

A search through PubMed (1970-2013) was performed on primary articles with the following search terms: RA, AS, PsA, or synovial fluid. This search was combined with keywords reflecting processes of atherothrombosis: atherosclerosis, cardiovascular disease, coagulation, endothelial, fibrinolysis, mean platelet volume, microparticles, platelet, platelet count and mass, thrombosis, and thrombus. Together, this comprehensive search resulted in 55 articles, containing data on changes in bloodrelated parameters from patients with RA, AS, or PsA, with respect to platelet count or function, leukocyte function, and markers of inflammation, endothelial activation, coagulation, or fibrinolysis. Table 1 lists the findings and indicates the numbers of studies, where specific prothrombotic or proinflammatory changes have been reported.

Table 1

Reported blood-related parameters reflecting a prothrombotic or proinflammatory state in patients with chronic arthritis

\begin{tabular}{|c|c|c|c|}
\hline Parameter & RA & AS & PsA \\
\hline \multicolumn{4}{|l|}{ Platelet mass } \\
\hline Mean platelet volume $\uparrow$ & $2 / 3[57-59]$ & $1 / 2[58,60]$ & $1 / 1[61]$ \\
\hline Platelet count $\uparrow$ & $11 / 13[10,20,21,27,57-59,62-67]$ & $3 / 4[21,58,60,68]$ & $0 / 1[21]$ \\
\hline Platelet microparticles $\uparrow$ & $1 / 4[26,27,67,69]$ & $0 / 1[70]$ & \\
\hline \multicolumn{4}{|l|}{ Platelet activation } \\
\hline Platelet aggregation $\uparrow$ & $4 / 5[20-24]$ & $1 / 1[21]$ & $2 / 2[21,25]$ \\
\hline Integrin $\alpha_{\mathrm{II}} \beta_{3}$ activation $\uparrow$ & $1 / 1[53]$ & - & - \\
\hline P-selectin (CD62P) expression $\uparrow$ & $2 / 3[27,53,71]$ & $1 / 1[68]$ & $0 / 1[72]$ \\
\hline CD63 expression $\uparrow$ & $1 / 1[71]$ & $1 / 1[68]$ & - \\
\hline \multicolumn{4}{|l|}{ Platelet-derived mediators } \\
\hline$\beta$-Thromboglobulin (CXCL7) $\uparrow$ & $0 / 1[53]$ & - & - \\
\hline Platelet factor 4 (CXCL4) $\uparrow$ & $0 / 1[64]$ & - & - \\
\hline RANTES (CCL5) $\uparrow$ & $1 / 1[26]$ & - & - \\
\hline sCD40L $\uparrow$ & $1 / 1[27]$ & - & $0 / 1[72]$ \\
\hline \multicolumn{4}{|l|}{ Leukocyte activation } \\
\hline CD11b and CD64 expression $\uparrow$ & $5 / 5[26,27,53,57,59]$ & $1 / 1[60]$ & - \\
\hline Platelet-monocyte complexes $\uparrow$ & $2 / 2[27,53]$ & - & $1 / 1[72]$ \\
\hline Platelet-neutrophil complexes $\uparrow$ & $1 / 2[27,53]$ & - & $0 / 1[72]$ \\
\hline sL-selectin (sCD62L) $\uparrow$ & $1 / 3[73-75]$ & - & - \\
\hline sICAM-3 (sCD50) $\uparrow$ & $1 / 1[73]$ & - & - \\
\hline \multicolumn{4}{|l|}{ Proinflammatory mediators } \\
\hline C-reactive protein (CRP) $\uparrow$ & $16 / 16[21,26,27,39,53,57-59,65-67,71,76-79]$ & $7 / 7[21,58,60,70,71,80,81]$ & $1 / 1[21]$ \\
\hline $\mathrm{ESR} \uparrow$ & $14 / 14[21,26,27,53,58,59,65-67,71,76-78,82]$ & $5 / 5[21,58,60,68,80]$ & $1 / 1[21]$ \\
\hline $\mathrm{IL}-1 \beta \uparrow$ & $2 / 2[10,39]$ & - & - \\
\hline $\mathrm{IL}-4 \uparrow$ & $1 / 1[10]$ & - & - \\
\hline IL-6 $\uparrow$ & $8 / 8[10,26,39,53,57,66,76,78]$ & $1 / 1[81]$ & - \\
\hline IL-8 $\uparrow$ & $1 / 1[26]$ & - & - \\
\hline $\mathrm{IL}-18 \uparrow$ & $1 / 1[83]$ & - & $0 / 1[83]$ \\
\hline $\mathrm{MCP}-1 \uparrow$ & $1 / 1[26]$ & - & - \\
\hline $\mathrm{MPO} \uparrow$ & $2 / 2[57,79]$ & - & - \\
\hline TNF- $\alpha \uparrow$ & $3 / 3[39,53,78]$ & - & - \\
\hline \multicolumn{4}{|l|}{ Vascular adaptation } \\
\hline Intima-media thickness $\uparrow$ & $2 / 2[77,82]$ & $1 / 2[80,84]$ & - \\
\hline Macrovascular dilatation $\downarrow$ & $1 / 2[66,85]$ & $2 / 2[80,84]$ & - \\
\hline Microvascular dilatation $\downarrow$ & $2 / 4[66,79,86,87]$ & $1 / 1[88]$ & - \\
\hline Angiogenesis $\uparrow$ & - & $1 / 1[88]$ & - \\
\hline Thrombomodulin $\uparrow$ & $1 / 1[89]$ & $1 / 1[81]$ & - \\
\hline \multicolumn{4}{|l|}{ Endothelial activation } \\
\hline sE-selectin (sCD62E) $\uparrow$ & $3 / 7[27,39,65,66,73,75,76,82,90]$ & - & $1 / 1[72]$ \\
\hline sP-selectin $(\mathrm{sCD} 62 \mathrm{P}) \uparrow$ & $4 / 6[53,57,73-75,90]$ & - & - \\
\hline sICAM-1 (sCD54) $\uparrow$ & $6 / 7[26,39,66,73,76,82,90]$ & - & - \\
\hline sVCAM-1 (sCD106) $\uparrow$ & $3 / 4[39,66,73,90]$ & - & - \\
\hline VEGF $\uparrow$ & $1 / 2[26,66]$ & - & - \\
\hline \multicolumn{4}{|l|}{ Coagulation and fibrinolysis } \\
\hline D-dimer $\uparrow$ & $5 / 5[53,76,78,82,91]$ & - & - \\
\hline Factor VIII $\uparrow$ & $1 / 1[92]$ & - & - \\
\hline Fibrinogen $\uparrow$ & $3 / 3[53,91,92]$ & $0 / 1[80]$ & - \\
\hline Fragment $1+2 \uparrow$ & $2 / 3[53,69,78]$ & - & - \\
\hline PAI- $1 \uparrow$ & $3 / 4[76,82,91,93]$ & $0 / 1[81]$ & - \\
\hline TFPI $\uparrow$ & $1 / 1[92]$ & - & - \\
\hline Tissue factor $\uparrow$ & - & $1 / 1[94]$ & - \\
\hline Thrombin generation $\uparrow$ & $1 / 1[95]$ & $1 / 1[96]$ & - \\
\hline Thrombin-antithrombin complex $\uparrow$ & $1 / 2[27,69]$ & $0 / 1[81]$ & - \\
\hline $\mathrm{tPA} \uparrow$ & $1 / 4[76,82,91,93]$ & $0 / 1[81]$ & - \\
\hline $\mathrm{uPA} \uparrow$ & $1 / 1[97]$ & - & - \\
\hline $\mathrm{vWF} \uparrow$ & $4 / 7[66,76,77,82,91,93,98]$ & $1 / 1[81]$ & - \\
\hline
\end{tabular}

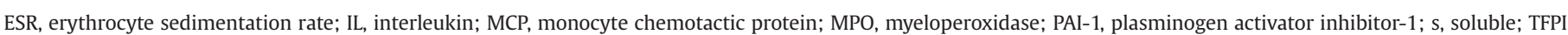
tissue factor pathway inhibitor; TNF, tumor necrosis factor; tPA, tissue plasminogen activator; VEGF, vascular endothelial growth factor; vWF, von Willebrand factor. 

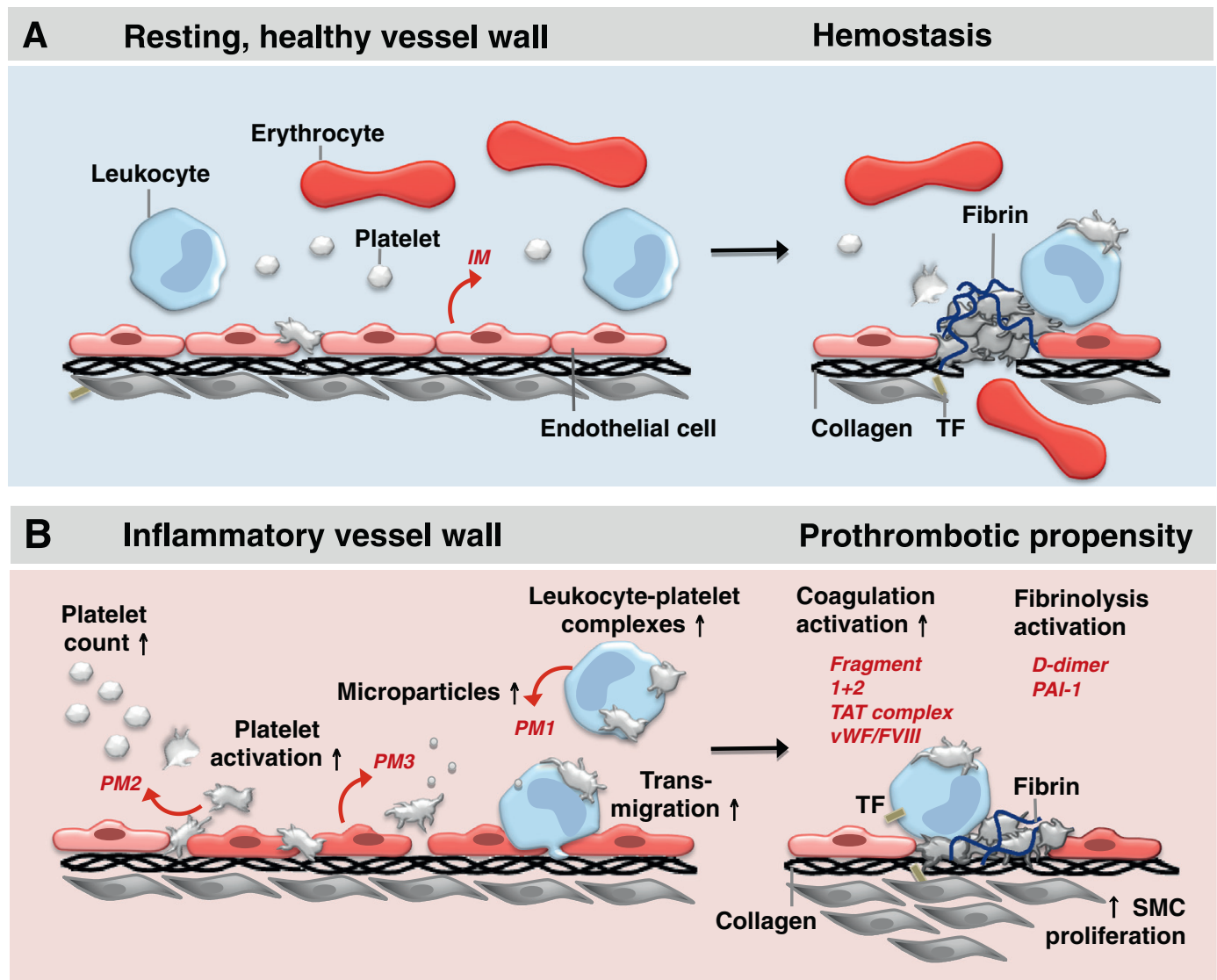

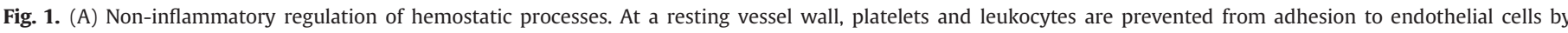

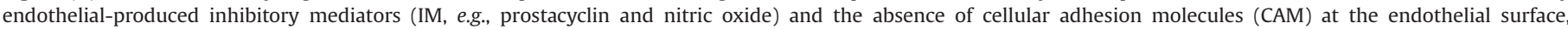

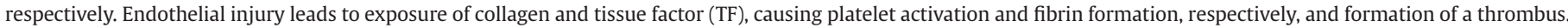

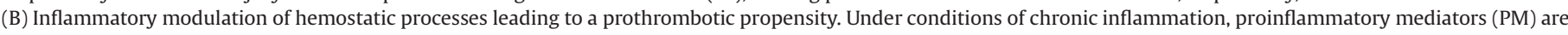

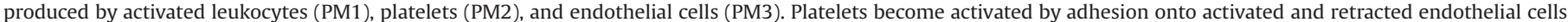

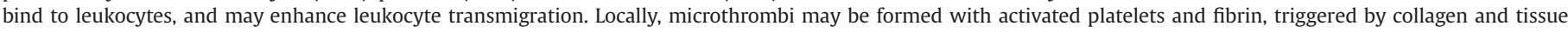
factor (TF), respectively. Coagulation and fibrinolysis products are released in the plasma. The PM also stimulate smooth muscle cell (SMC) proliferation.

\section{Results}

\section{Blood cell-vessel wall interactions in normal hemostasis}

Before discussing the aberrations in blood parameters reported in cases of chronic inflammation, we briefly recapitulate the fundamentals how blood cell interactions with the vessel wall are regulated in normal hemostasis [6]. In the non-inflamed, healthy vessel wall, the endothelial secretion of inhibitory mediators prevents adhesion of platelets, while leukocyte adhesion is limited by the absence of cellular adhesion molecules (CAMs) at the endothelial surface (Fig. 1A). Vascular damage results in exposure of subendothelial matrix proteins such as collagens to which platelets adhere and form aggregates and a secluding thrombus [7]. Exposed vascular tissue factor triggers the formation of thrombin and fibrin to consolidate the formed thrombus. These processes may also lead to limited leukocyte adhesion.

\section{Increased platelet mass and circulating microparticles in chronic} arthritis

The mass of circulating platelets has been identified as a blood parameter that associates with cardiovascular disease [8,9]. In 14 articles, a rise in platelet count or in mean platelet volume has been reported for patients with RA, AS, or PsA (Table 1). The increased mass of circulating platelets likely is a consequence of chronic inflammation, given the fact that several inflammatory mediators influence platelet production from megakaryocytes or can prolong platelet survival. A key mediator in this respect is interleukin-6 (IL-6), which has been shown to stimulate platelet production from megakaryocytes and is up regulated in blood from RA and AS patients [10]. However, mechanistic studies to demonstrate such a role of IL-6 in arthritis are still missing.

In 2 breakthrough studies with mice, a role of platelet-derived microparticles has been shown in experimental arthritis [11,12]. However, in clinical studies with RA or AS patients, increased circulating levels of microparticles were observed in only 1 out of 5 articles. Given the knowledge that microparticle shedding can be considered as a marker of platelet activation [13,14], this argues against an overall high activation state of the circulating platelets in chronic arthritis. On the other hand, local effects such as accumulation of platelet-derived as well as neutrophil- and monocyte-derived microparticles in the synovial fluid of the joints have been reported in RA patients $[11,15]$. By implication, activation of both platelets and leukocytes in the joints may lead to microparticle formation and subsequent aggravation of local inflammatory and procoagulant reactions $[16,17]$. To which extent these local processes integrate to a systemic prothrombotic propensity of the patients is unclear.

\section{Activated platelets interacting with leukocytes}

Platelets contain a large pool of bioactive proteins that are secreted from their $\alpha$-granules and can regulate a variety of 


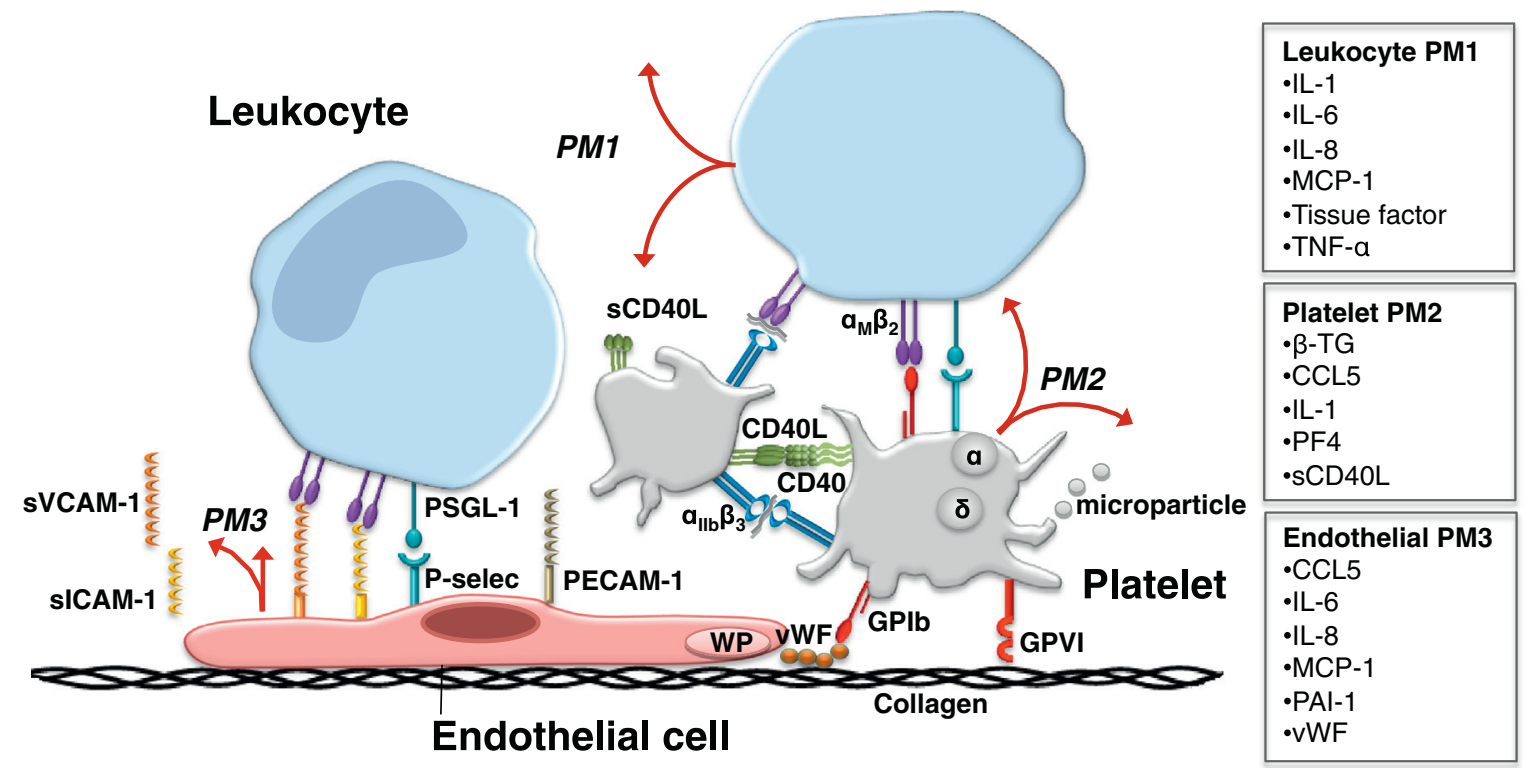

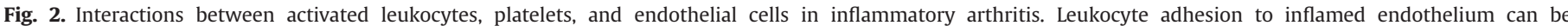

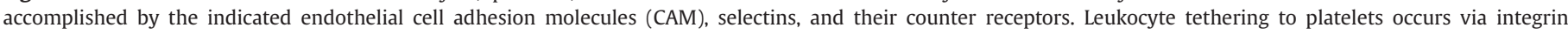

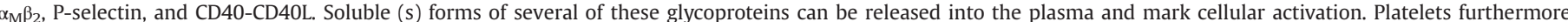

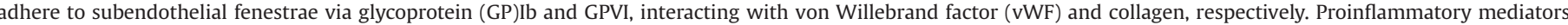
(PM) are produced by activated leukocytes (PM1), platelets (PM2), as well as endothelial cells (PM3). Key mediators are indicated in boxes.

intravascular processes, such as thrombus formation, vascular repair, and leukocyte activation [18]. Vice versa, inflammatory mediators derived from leukocytes can also potentiate the activation of platelets [19]. Hence, it is understandable that, in many studies with chronic inflammatory arthritis patients, evidence has been found for an increase in platelet activation. Mostly reported are higher tendencies in platelet aggregation and platelet secretion (Table 1).

In patients with RA, elevated $\alpha_{\mathrm{IIb}} \beta_{3}$ integrin activation and platelet aggregation has been documented for all common platelet agonists: adenosine diphosphate (ADP), arachidonic acid, collagen, epinephrine, and thrombin receptor-activating peptide (TRAP) [20-25]. With respect to the $\mathrm{P}_{2 \mathrm{Y}_{12}}$ receptor agonist ADP, aggregation is reported to be increased in 4 out of 5 articles studying RA patients (Table 1). Flow cytometric studies support these findings by showing that dense granule secretion (expression of P-selectin/ CD62P) and $\alpha$-granule secretion (expression of CD63) are increased in platelets from RA or AS patients.

Interestingly, circulating levels of the platelet secretion products ( $\beta$-thromboglobulin and platelet factor 4 ) seem to be unchanged in patients' blood samples, implying that the extent of systemic secretion is limited. Yet, 2 studies report elevated plasma levels of 2 other platelet products, namely CCL5 (RANTES) and soluble CD40L $[26,27]$. These mediators can be produced by non-classical secretion pathways, for example, via proteaseinduced shedding of soluble CD40L from the platelet membrane.

Platelets extensively interact with leukocytes in vascular diseases such as atherosclerosis and are regarded as central players in the pathophysiology of vascular inflammation [28]. Upon activation, platelets release a range of chemotactic cytokines and lipid mediators that influence the activation state of monocytes and other leukocytes [29]. Evidence for a proinflammatory role of platelets in RA comes from reports on increased levels of platelet-monocyte and platelet-neutrophil complexes in blood from these patients (Table 1). This is compatible with an increase in P-selectin expression at the platelet surface, as this glycoprotein is of key importance for the establishing of platelet-leukocyte contacts $[16,30]$. Conversely, activated leukocytes produce cytokines that can also modulate the platelet-activation process.
In particular, levels of monocyte-derived proinflammatory cytokines, such as IL-6, IL-8, and MCP-1, appear to be increased in RA plasma. Also, shedding of the leukocyte receptors, L-selectin, and ICAM-3 is increased in 2 out of 3 studies with patients with RA (Table 1). In the formation of these mediators, platelet activation may also play an intermediary role. For example, platelet inhibition was found to counterbalance the rises in IL-6 and the acute-phase reactant C-reactive protein in patients with acute cardiovascular disease [31]. Together with the erythrocyte sedimentation rate (ESR), plasma levels of C-reactive protein are the most frequently used markers for disease activity in patients with arthritis. As expected, the plasma levels of C-reactive protein and ESR were found to be increased in 22/22 studies examining patients with RA, AS, or PsA (Table 1). Platelets may further be implicated in the dissociation of the circulating pentameric form of C-reactive protein into monomers with more proinflammatory properties [32]. Taken together, these findings indicate that, in chronic arthritis, many of the reported changes in blood parameters point to an increase in platelet-leukocyte crosstalk linked to enhanced activation of these blood cells (Fig. 2).

\section{Leukocyte and endothelial activation}

Activated leukocytes strongly modulate the activation state of the vascular endothelium. Relevant mediators in this respect are IL- 6 and TNF- $\alpha$, the levels of which are consistently found to be elevated in plasma from RA patients (Table 1). Endothelial cells as well as monocytes that are stimulated with interleukins or TNF- $\alpha$ display increased procoagulant activity. Mechanistically, TNF- $\alpha$ induces the up-regulation of tissue factor and inhibits the activation of protein $\mathrm{C}$, both of which effects promote the coagulation process $[33,34]$. The cytokines IL- $1 \beta$ and IL- 8 have similar effects on monocytes. In line with a procoagulant propensity, IL-6 stimulates the hepatic production of fibrinogen, thus resulting in elevated plasma levels of this coagulant protein [35-37].

As reviewed elsewhere, there is consistent evidence that the pathogenesis of rheumatic diseases depends on persistent endothelial activation and vascular adaptation [38]. Literature reports indicate increases in arterial intima-media thickness, arterial 
stiffness, and angiogenesis (Table 1). Correspondingly, several studies with RA patients report on increased plasma levels of markers of endothelial activation, such as soluble fragments of ICAM-1, VCAM-1, and E-selectin, although this is not confirmed in all studies. The difference between studies may be explained by the small sample size and heterogeneity among the disease state of the patients. Mechanistically, there is evidence that elevation in leukocyte-derived TNF- $\alpha$ and IL-1 $\beta$ induces the up-regulation and shedding of CAM and selectin isoforms on the endothelium [39]. Once expressed at the endothelial surface membrane, these glycoproteins regulate leukocyte adhesion and infiltration [29]. Furthermore, activated endothelial cells can contribute to the inflammation process by producing mediators like IL-1, -6, -8, TNF- $\alpha$, MCP-1, and CCL5 [40]. Endothelial activation also leads to retraction of these cells and exposure of the subendothelial matrix to the blood stream, thus providing sites for platelet adhesion and activation $[28,41]$.

Taken together, this leads to a model in which chronic arthritis drives and is driven by leukocyte interactions with platelets and endothelial cells, mediated by multiple proinflammatory mediators, many of which also have a role in prothrombotic reactions (Fig. 2). Jointly, these interactions thus create a proinflammatory and prothrombotic environment.

\section{Plasmatic coagulation, fibrinolysis, and immunity}

In the literature, ample support is provided for increased activity of the plasmatic coagulation and fibrinolytic systems in patients with inflammatory joint diseases (Table 1). An increase in thrombin generation has been noticed in plasmas from RA and AS patients. This is considered to be relevant, since thrombin is a central enzyme in the coagulation cascade that activates platelets and cleaves fibrinogen into fibrin [6]. In agreement with this, plasma levels of the thrombin-generation products, fragment $1+$ 2 , and thrombin-antithrombin (TAT) complex are increased in RA patients (Table 1). The reported increases in plasma levels of coagulation factor VIII and fibrinogen may also point to an increased procoagulant potential in these patients (Table 1 and Fig. 1B).

In 4 out of 6 studies with RA and AS patients, increased plasma levels of von Willebrand factor (vWF) have been reported (Table 1), which is an indication of endothelial activation and links to increased procoagulant activity. Once released by activated endothelial cells, vWF acts as a carrier in plasma for factor VIII and plays an important role in shear-dependent platelet adhesion and thrombus formation [6].

There is limited evidence for altered fibrinolytic activity in RA patients. The degradation of fibrin relies on plasminogen activation by tissue plasminogen activator (tPA) and urokinase plasminogen activator (uPA). Increased levels of uPA but not of tPA have been found in the synovial fluid and blood plasma from RA patients (Table 1). The fibrin degradation product, D-dimer, commonly used as a marker of fibrinolysis, is consistently high in RA plasma. On the other hand, also the anti-fibrinolytic protein, plasminogen activator inhibitor-1 (PAI-1), released by activated endothelium, is higher in these patients.

Several recent studies point to connections between inflammation and alterations in innate and adaptive immunity in RA. In a mouse model of spontaneous autoantibody-driven arthritis, a role of the proinflammatory complement factor $\mathrm{C} 5$ has been identified in supporting the coagulation process [42]. In another study, cleavage of complement factor $\mathrm{C} 5 \mathrm{a}$ by carboxypeptidase $\mathrm{B}$ in a thrombomodulin (endothelium)-dependent way was found to suppress the inflammation process [43]. Recently, citrullinated histone 4, present in pathogen-killing neutrophil extracellular traps (NETs), was identified as a substrate for RA-specific anti-citrullinated peptides antibodies [44]. Taken together, these data point to coagulation, fibrinolyis, and immunity-induced procoagulant changes in the blood from arthritis patients, which at least partly can be linked to an increased activation state of the endothelium.

\section{Normalization of prothrombotic propensity by anti-arthritis medication}

Non-steroidal anti-inflammatory drugs (NSAIDs) are conventionally used as a first-line treatment of chronic arthritis to relieve pain, but they may promote cardiovascular risk. The latter effect has been attributed to NSAID-mediated inhibition of the COX2dependent formation of prostacyclin in the endothelium, thereby abrogating the platelet-inhibiting activity of prostacyclin $[45,46]$. Other compounds used to slow down the progression of RA are the so-called disease-modifying anti-rheumatic drugs (DMARDs), with methotrexate as a standard. These drugs, targeted at T cells, are considered to have a beneficial effect on cardiovascular diseaserelated mortality [47]. However, because methotrexate (or other DMARDs) is often given in combination therapy with NSAIDs, a normalizing effect regarding cardiovascular risk is not always apparent [1].

An improved effect on cardiovascular disease is also reported for the biopharmaceutical TNF- $\alpha$ inhibitors (e.g., adalimumab, certolizumab, etanercept, golimumab, and infliximab), which are prescribed either as first-line treatment or to patients who are non-responsive to other treatments [1]. Considering that TNF- $\alpha$ is a master regulator of inflammation, TNF- $\alpha$ blockers thus help to suppress the onset of this process [48-52].

From the analyzed literature, it is evident that at least several of the prothrombotic parameters become normalized in rheumatoid patients who are treated with methotrexate or TNF- $\alpha$ blockers (Table 2). As aimed for, all types of therapy reduce the plasma levels of key inflammatory mediators (ESR, C-reactive protein, TNF- $\alpha$, and IL-6). A consistent decrease in platelet mass and a reduction in endothelial activation markers (soluble selectins and ICAM) so far have only been reported for conventional or TNF$\alpha$-directed therapy. A single, small-sized study reported no more than minimal effects on platelet-activation processes after treatment with methotrexate or TNF- $\alpha$ blockers [53]. Interestingly, all current treatments appear to normalize coagulation- and fibrinolysis-related parameters (Table 2).

Although anti-platelet agents may effectively suppress inflammatory processes $[54,55]$, treatment strategies to reduce plateletdependent inflammation processes in arthritis are not available yet. A potentially interesting target in this respect is platelet P-selectin, given its key role in forming interactions of leukocytes with platelets and endothelial cells. So far, the effects on arthritis of common platelet inhibitors targeted at cyclooxygenase (aspirin) or the $\mathrm{P}_{2} \mathrm{Y}_{12}$ receptor for ADP (clopidogrel and prasugrel) have not systematically been studied.

\section{Discussion and conclusion}

Overviewing the literature, it appears that the prothrombotic propensity in patients with inflammatory arthritis is a consequence of the combined activation of the platelets, leukocytes, and endothelium, thereby affecting the coagulation system. Proinflammatory mediators released by leukocytes, platelets, and endothelial cells may drive the intercellular cross talk. The fragmented evidence so far indicates that in these patients, the mass of platelets is increased; the platelet-activation tendency is higher; platelet-leukocyte complexes are formed; coagulation factors accumulate; and (local) activation of the coagulation and 
Table 2

Reported normalizing effects of anti-arthritis medication on blood-related prothrombotic and proinflammatory parameters

\begin{tabular}{|c|c|c|c|}
\hline \multirow[t]{2}{*}{ Parameter } & \multicolumn{3}{|l|}{ Medication } \\
\hline & Conventional $^{\mathrm{a}}$ & Medication methotrexate & TNF- $\alpha$ directed \\
\hline \multicolumn{4}{|l|}{ Platelet mass } \\
\hline Mean platelet volume $\downarrow$ & $2 / 3[58-60]$ & - & $1 / 2[60,100]$ \\
\hline Platelet count $\downarrow$ & $4 / 5[58-60,90,99]$ & - & $2 / 2[60,100]$ \\
\hline Platelet mass $\downarrow$ & $1 / 1[60]$ & - & $1 / 1[60]$ \\
\hline \multicolumn{4}{|l|}{ Platelet activation } \\
\hline CD62P expression $\downarrow$ & - & $0 / 1[53]$ & $0 / 1[53]$ \\
\hline$\beta$-Thromboglobulin (CXCL7) $\downarrow$ & - & $0 / 1[53]$ & $1 / 1[53]$ \\
\hline \multicolumn{4}{|l|}{ Proinflammatory mediators } \\
\hline C-reactive protein (CRP) $\downarrow$ & $5 / 5[58-60,90,99]$ & $1 / 1[78]$ & $5 / 5[53,60,78,88,101]$ \\
\hline $\mathrm{ESR} \downarrow$ & $4 / 4[58-60,99]$ & $1 / 1[78]$ & $7 / 7[53,60,78,85,88,100,102]$ \\
\hline $\mathrm{TNF}-\alpha \downarrow$ & - & $1 / 1[78]$ & $1 / 1[78]$ \\
\hline IL-6 $\downarrow$ & - & - & $2 / 2[53,101]$ \\
\hline Leukocyte count $\downarrow$ & - & $1 / 1[53]$ & - \\
\hline \multicolumn{4}{|l|}{ Endothelial activation } \\
\hline sE-selectin $\downarrow$ & $1 / 1[99]$ & - & - \\
\hline sP-selectin $\downarrow$ & $1 / 1[90]$ & - & $1 / 1[53]$ \\
\hline sICAM- $1 \downarrow$ & $1 / 1[90]$ & - & - \\
\hline \multicolumn{4}{|l|}{ Vascular adaptation } \\
\hline Intima-media thickness $\downarrow$ & - & - & $1 / 1[85]$ \\
\hline Macrovascular dilatation $\uparrow$ & - & - & $6 / 6[85,88,102-105]$ \\
\hline Angiogenesis $\downarrow$ & - & & $0 / 1[88]$ \\
\hline \multicolumn{4}{|l|}{ Coagulation and fibrinolysis } \\
\hline D-dimer $\downarrow$ & - & $2 / 2[53,78]$ & $1 / 1[78]$ \\
\hline Fibrinogen $\downarrow$ & - & - & $3 / 3[53,101,105]$ \\
\hline Fragment $1+2 \downarrow$ & - & $2 / 2[53,78]$ & $1 / 1[78]$ \\
\hline
\end{tabular}

Abbreviations: see Table 1.

${ }^{a}$ Treatment with conventional disease-modifying anti-rheumatic drugs (DMARD), non-steroidal anti-inflammatory drug (NSAID), or steroids.

fibrinolysis systems results in the circulation of thrombin and fibrin products (Fig. 1B). The moderately activated platelets, leukocytes, and endothelial cells shed soluble forms of CAM and selectin receptors-perhaps in a manner dependent on the actual disease state-that serve as cell activation markers and may have biological properties themselves. Yet, there is little evidence for high in-situ platelet activation and massive release of plateletactivation products, such as observed in acute prothrombotic situations, e.g., in overt peripheral arterial disease. Together, this points to a mechanism of moderate or local blood cell activation, e.g., mediated and enforced by proinflammatory cytokines, which stimulates platelet interaction with leukocytes and endothelial cells and enhances leukocyte recruitment.

Because of their multi-faceted interactions with other cells of the cardiovascular system, platelets are nowadays considered as central regulatory cellular effectors of inflammation in vascular diseases $[19,56]$. From the current analysis, it seems that platelets-in crosstalk with leukocytes, the endothelium, and the coagulation system-are also important in the switch from chronic inflammatory into prothrombotic conditions linked to cardiovascular disease. However, more systematic trials are needed to identify the key markers of platelet or coagulation activation for assessment of the risk of cardiovascular disease in patients with rheumatoid disorders. This may lead to more personalized therapy to reduce the comorbidity and improved long-term outcome of these patients in terms of disability, hospitalization, and mortality.

The effectiveness of pharmacological treatment of arthritis, especially with TNF- $\alpha$ blockers, appears to be accompanied with normalization not only of leukocyte function but also of vascular, platelet, and coagulant activities. Hence, it seems that recuperation of the leukocyte-driven inflammation process leads to readjustment of many of the prothrombotic changes in patients with chronic arthritis. Yet, the evidence for this scenario is scattered among articles, mostly analyzing small groups of patients. Larger and more coherent studies are required to confirm this treatment effect further.

\section{Acknowledgments}

We thank Dr. A.E. Boonen and Dr. A.M. van Tubergen, Division of Rheumatology, Maastricht University Medical Center for reading the article and for valuable suggestions.

\section{References}

[1] van den Oever IA, Sattar N, Nurmohamed MT. Thromboembolic and cardiovascular risk in rheumatoid arthritis: role of the haemostatic system. Ann Rheum Dis 2014;73:954-7.

[2] Avina-Zubieta JA, Thomas J, Sadatsafavi M, Lehman AJ, Lacaille D. Risk of incident cardiovascular events in patients with rheumatoid arthritis: a metaanalysis of observational studies. Ann Rheum Dis 2012;71:1524-9.

[3] Papagoras C, Voulgari PV, Drosos AA. Atherosclerosis and cardiovascular disease in the spondyloarthritides, particularly ankylosing spondylitis and psoriatic arthritis. Clin Exp Rheumatol 2013;31:612-20.

[4] Aletaha D, Neogi T, Silman AJ, Funovits J, Felson DT, Bingham CO, et al. 2010 rheumatoid arthritis classification criteria: an American College of Rheumatology/European League Against Rheumatism collaborative initiative. Ann Rheum Dis 2010;69:1580-8.

[5] Gonzalez A, Maradit Kremers H, Crowson CS, Ballman KV, Roger VL, Jacobsen SJ, et al. Do cardiovascular risk factors confer the same risk for cardiovascular outcomes in rheumatoid arthritis patients as in non-rheumatoid arthritis patients? Ann Rheum Dis 2008;67:64-9.

[6] Versteeg HH, Heemskerk JW, Levi M, Reitsma PH. New fundamentals in hemostasis. Physiol Rev 2013:93:327-58.

[7] Cosemans JM, Angelillo-Scherrer A, Mattheij NJ, Heemskerk JW. The effects of arterial flow on platelet activation, thrombus growth, and stabilization. Cardiovasc Res 2013;99:342-52. 
[8] Gasparyan AY, Stavropoulos-Kalinoglou A, Mikhailidis DP, Douglas KM, Kitas GD. Platelet function in rheumatoid arthritis: arthritic and cardiovascular implications. Rheumatol Int 2011;31:153-64.

[9] Gieger C, Radhakrishnan A, Cvejic A, Tang W, Porcu E, Pistis G, et al. New gene functions in megakaryopoiesis and platelet formation. Nature 2011;480:201-8.

[10] Ertenli I, Haznedaroglu IC, Kiraz S, Celik I, Calguneri M, Kirazhi S. Cytokines affecting megakaryocytopoiesis in rheumatoid arthritis with thrombocytosis. Rheumatol Int 1996;16:5-8.

[11] Boilard E, Nigrovic PA, Larabee K, Watts GF, Coblyn JS, Weinblatt ME, et al. Platelets amplify inflammation in arthritis via collagen-dependent microparticle production. Science 2010;327:580-3.

[12] Cloutier N, Pare A, Farndale RW, Schumacher HR, Nigrovic PA, Lacroix S, et al. Platelets can enhance vascular permeability. Blood 2012;120:1334-43.

[13] Heemskerk JW, Kuijpers MJ, Munnix IC, Siljander PR. Platelet collagen receptors and coagulation. A characteristic platelet response as possible target for antithrombotic treatment. Trends Cardiovasc Med 2005;15:86-92.

[14] Vasina EM, Cauwenberghs S, Staudt M, Feijge MA, Weber C, Koenen RR, et al. Aging- and activation-induced platelet microparticles suppress apoptosis in monocytic cells and differentially signal to proinflammatory mediator release. Am J Blood Res 2013;3:107-23.

[15] Montecucco F, Mach F. Common inflammatory mediators orchestrate pathophysiological processes in rheumatoid arthritis and atherosclerosis. Rheumatology 2009;48:11-22.

[16] Vasina E, Heemskerk JWM, Weber C, Koenen RR. Platelets and plateletderived microparticles in vascular inflammatory disease. Inflamm Allergy Drug Targets 2010;9:346-54.

[17] Van der Meijden PE, van Schilfgaarde M, van Oerle R, Renné T, ten Cate H, Spronk HM. Platelet- and erythrocyte-derived microparticles trigger thrombin generation via factor XIIa. J Thromb Haemost 2012;10:1355-62.

[18] Smyth SS, McEver RP, Weyrich AS, Morrell CN, Hoffman MR, Arepally GM, et al. Platelet functions beyond hemostasis. J Thromb Haemost 2009;7: 1759-66.

[19] Rondina MT, Weyrich AS, Zimmermann GA. Platelets as cellular effectors of inflammation in vascular diseases. Circ Res 2013;112:1506-19.

[20] Colli S, Maderna P, Tremoli E, Colombo F, Canesi B. Platelet function in rheumatoid arthritis. Scand J Rheumatol 1982;11:139-43.

[21] Mac Mullan PA, Peace AJ, Madigan AM, Tedesco AF, Kenny D, McCarthy GM. Platelet hyper-reactivity in active inflammatory arthritis is unique to the adenosine diphosphate pathway: a novel finding and potential therapeutic target. Rheumatology 2010;49:240-5.

[22] Endresen GK. Investigation of blood platelets in synovial fluid from patients with rheumatoid arthritis. Scand J Rheumatol 1981;10:204-8.

[23] Riddle JM, Bluhm GB, Pitchford WC, McElroy H, Jimenea C, Leisen J, et al. A comparative study of platelet reactivity in arthritis. Ann N Y Acad Sci 1981; 370:22-9.

[24] Farr M, Scott DL, Constable TJ, Hawker RJ, Hawkins CF, Stuart J. Thrombocytosis of active rheumatoid disease. Ann Rheum Dis 1983;42:545-9.

[25] Di Minno MN, Iervolino S, Peluso R, Scarpa R, Di Minno G. Platelet reactivity and disease activity in subjects with psoriatic arthritis. J Rheumatol 2012;39: 334-6.

[26] Berckmans RJ, Nieuwland R, Kraan MC, Schaap MC, Pots D, Smeets TJ, et al. Synovial microparticles from arthritic patients modulate chemokine and cytokine release by synoviocytes. Arthritis Res Ther 2005;7:R536-44.

[27] Pamuk GE, Vural O, Turgut B, Demir M, Pamuk ON, Cakir N. Increased platelet activation markers in rheumatoid arthritis: are they related with subclinical atherosclerosis? Platelets 2008;19:146-54.

[28] Projahn D, Koenen RR. Platelets: key players in vascular inflammation. J Leukoc Biol 2012;92:1167-75.

[29] Koenen RR, Weber C. Therapeutic targeting of chemokine interactions in atherosclerosis. Nat Rev Drug Discov 2010;9:141-53.

[30] Schmitt-Sody M, Metz P, Klose A, Gottschalk O, Zysk S, Hausdorf J, et al. In vivo interactions of platelets and leucocytes with the endothelium in murine antigen-induced arthritis: the role of P-selectin. Scand J Rheumatol 2007;36: $311-9$.

[31] Lincoff AM, Kereiakes DJ, Mascelli MA, Deckelbaum LI, Barnathan ES, Patel KK, et al. Abciximab suppresses the rise in levels of circulating inflammatory markers after percutaneous coronary revascularization. Circulation 2001; 104:163-7.

[32] Eisenhardt SU, Habersberger J, Murphy A, Chen YC, Woollard KJ, Bassler N, et al. Dissociation of pentameric to monomeric C-reactive protein on activated platelets localizes inflammation to atherosclerotic plaques. Circ Res 2009;105:128-37.

[33] Zhang H, Park Y, Wu J, Chen X, Lee S, Yang J, et al. Role of TNF- $\alpha$ in vascular dysfunction. Clin Sci 2009;116:219-30.

[34] Metsios GS, Stavropoulos-Kalinoglou A, Sandoo A, van Zanten JJ, Toms TE, John $\mathrm{H}$, et al. Vascular function and inflammation in rheumatoid arthritis: the role of physical activity. Open Cardiovasc Med J 2010;4:89-96.

[35] ten Cate JW, van der Poll T, Levi M, ten Cate H, van Deventer SJ. Cytokines: triggers of clinical thrombotic disease. Thromb Haemost 1997;78:415-9.

[36] Mantovani A, Sozzani S, Vecchi A, Introna M, Allavena P. Cytokine activation of endothelial cells: new molecules for an old paradigm. Thromb Haemost 1997;78:406-14.

[37] Grignani G, Maiolo A. Cytokines and hemostasis. Haematologica 2000;85: 967-72.

[38] Szekanecz Z, Koch AE. Vascular involvement in rheumatic diseases: "vascular rheumatology". Arthritis Res Ther 2008:10:224.
[39] Dessein PH, Joffe BI, Singh S. Biomarkers of endothelial dysfunction, cardiovascular risk factors and atherosclerosis in rheumatoid arthritis. Arthritis Res Ther 2005;7:R634-43.

[40] Krishnaswamy G, Kelley J, Yerra L, Smith JK, Chi DS. Human endothelium as a source of multifunctional cytokines: molecular regulation and possible role in human disease. J Interferon Cytokine Res 1999;19:91-104.

[41] Jackson SP. Arterial thrombosis-insidious, unpredictable and deadly. Nat Med 2011;17:1423-36.

[42] Auger JL, Haasken S, Binstadt BA. Autoantibody-mediated arthritis in the absence of C3 and activating FC $\gamma$ receptors: C5 is activated by the coagulation cascade. Arthritis Res Ther 2012;14:R269.

[43] Song JJ, Hwang I, Cho KH, Garcia MA, Kim AJ, Wang TH, et al. Plasma carboxypeptidase B downregulates inflammatory responses in autoimmune arthritis. J Clin Invest 2011;121:3517-27.

[44] Pratesi F, Dioni I, Tommasi C, Alcaro MC, Paolini I, Barbetti F, et al. Antibodies from patients with rheumatoid arthritis target citrullinated histone 4 contained in neutrophils extracellular traps. Ann Rheum Dis 2014;73:1414-22.

[45] Funk CD, FitzGerald GA. COX-2 inhibitors and cardiovascular risk. J Cardiovasc Pharmacol 2007;50:470-9.

[46] Griffin MR. High-dose non-steroidal anti-inflammatories: painful choices Lancet 2013:382:746-8.

[47] Gossec L, Smolen JS, Gaujoux-Viala C, Ash Z, Marzo-Ortega H, van der Heijde $D$, et al. European League Against Rheumatism recommendations for the management of psoriatic arthritis with pharmacological therapies. Ann Rheum Dis 2012;71:4-12.

[48] Choi HK, Hernan MA, Seeger JD, Robins JM, Wolfe F. Methotrexate and mortality in patients with rheumatoid arthritis: a prospective study. Lancet 2002:359:1173-7.

[49] Jacobsson LT, Turesson C, Gulfe A, Kapetanovic MC, Petersson IF, Saxne T et al. Treatment with tumor necrosis factor blockers is associated with a lower incidence of first cardiovascular events in patients with rheumatoid arthritis. J Rheumatol 2005;32:1213-8.

[50] van Halm VP, Nurmohamed MT, Twisk JW, Dijkmans BA, Voskuyl AE. Disease-modifying antirheumatic drugs are associated with a reduced risk for cardiovascular disease in patients with rheumatoid arthritis: a case control study. Arthritis Res Ther 2006;8:R151.

[51] Naranjo A, Sokka T, Descalzo MA, Calvo-Alen J, Horslev-Petersen K, Luukkainen RK, et al. Cardiovascular disease in patients with rheumatoid arthritis: results from the QUEST-RA study. Arthritis Res Ther 2008;10:R30.

[52] Dixon WG, Watson KD, Lunt M, Hyrich KL, Silman AJ, Symmons DP. Reduction in the incidence of myocardial infarction in patients with rheumatoid arthritis who respond to anti-tumor necrosis factor alpha therapy: results from the British Society for Rheumatology Biologics Register. Arthritis Rheum 2007;56:2905-12.

[53] Bunescu A, Seideman P, Lenkei R, Levin K, Egberg N. Enhanced Fcy receptor I, $\alpha \mathrm{M} \beta 2$ integrin receptor expression by monocytes and neutrophils in rheumatoid arthritis: interaction with platelets. J Rheumatol 2004;31:2347-55.

[54] Pitchford SC. Novel uses for anti-platelet agents as anti-inflammatory drugs. Br J Pharmacol 2007; 152:987-1002.

[55] Arazi HC, Badimon JJ. Anti-inflammatory effects of anti-platelet treatment in atherosclerosis. Curr Pharm Des 2012;18:4311-25.

[56] Morrell CN, Aggrey AA, Chapman LM, Modjeski KL. Emerging roles for platelets as immune and inflammatory cells. Blood 2014;123:2759-67.

[57] Milovanovic M, Nilsson E, Jaremo P. Relationships between platelets and inflammatory markers in rheumatoid arthritis. Clin Chim Acta 2004;343: 237-40.

[58] Kisacik B, Tufan A, Kalyoncu U, Karadag O, Akdogan A, Ozturk MA, et al Mean platelet volume (MPV) as an inflammatory marker in ankylosing spondylitis and rheumatoid arthritis. Joint Bone Spine 2008;75:291-4.

[59] Yazici S, Yazici M, Erer B, Erer B, Calik Y, Ozhan H, et al. The platelet indices in patients with rheumatoid arthritis: mean platelet volume reflects disease activity. Platelets 2010;21:122-5.

[60] Yazici S, Yazici M, Erer B, Calik Y, Bulur S, Ozhan H, et al. The platele functions in patients with ankylosing spondylitis: anti-TNF- $\alpha$ therapy decreases the mean platelet volume and platelet mass. Platelets 2010;21: $126-31$.

[61] Canpolat F, Akpinar H, Eskioglu F. Mean platelet volume in psoriasis and psoriatic arthritis. Clin Rheumatol 2010;29:325-8.

[62] Hutchinson RM, Davis P, Jayson MI. Thrombocytosis in rheumatoid arthritis. Ann Rheum Dis 1976;35:138-42.

[63] Farr M, Wainwright A, Salmon M, Hollywell CA, Bacon PA. Platelets in the synovial fluid of patients with rheumatoid arthritis. Rheumatol Int 1984;4: $13-7$.

[64] Endresen GK. Evidence for activation of platelets in the synovial fluid from patients with rheumatoid arthritis. Rheumatol Int 1989:9:19-24.

[65] Egerer K, Hertzer J, Feist E, Albrecht A, Rudolph PE, Dorner T, et al. sE-selectin for stratifying outcome in rheumatoid arthritis. Arthritis Rheum 2003;49: 546-8.

[66] Foster W, Lip GY, Raza K, Carruthers D, Blann AD. An observational study of endothelial function in early arthritis. Eur J Clin Invest 2012;42:510-6.

[67] Knijff-Dutmer EA, Koerts J, Nieuwland R, Kalsbeek-Batenburg EM, van de Laar MA. Elevated levels of platelet microparticles are associated with disease activity in rheumatoid arthritis. Arthritis Rheum 2002;46:1498-503.

[68] Wang F, Yan CG, Xiang HY, Xing T, Wang NS. The significance of platelet activation in ankylosing spondylitis. Clin Rheumatol 2008;27:767-9. 
[69] Berckmans RJ, Nieuwland R, Tak PP, Boing AN, Romijn FP, Kraan MC, et al. Cell-derived microparticles in synovial fluid from inflamed arthritic joints support coagulation exclusively via a factor VII-dependent mechanism. Arthritis Rheum 2002;46:2857-66.

[70] Sari I, Bozkaya G, Kirbiyik H, Alacacioglu A, Ates H, Sop G, et al. Evaluation of circulating endothelial and platelet microparticles in men with ankylosing spondylitis. J Rheumatol 2012;39:594-9.

[71] Wang F, Wang NS, Yan CG, Li JH, Tang LQ. The significance of platelet activation in rheumatoid arthritis. Clin Rheumatol 2007:26:768-71.

[72] Pamuk GE, Nuri Pamuk O, Orum H, Arican O, Turgut B, Demir M. Elevated platelet-monocyte complexes in patients with psoriatic arthritis. Platelets 2009;20:493-7.

[73] Littler AJ, Buckley CD, Wordsworth P, Collins I, Martinson J, Simmons DL. A distinct profile of six soluble adhesion molecules (ICAM-1, ICAM-3, VCAM1, E-selectin, L-selectin and P-selectin) in rheumatoid arthritis. Br J Rheumatol 1997;36:164-9.

[74] Sfikakis PP, Charalambopoulos D, Vaiopoulos G, Mavrikakis M. Circulating P- and L-selectin and T-lymphocyte activation and patients with autoimmune rheumatic diseases. Clin Rheumatol 1999;18:28-32.

[75] Ates A, Kinikli G, Turgay M, Duman M. Serum-soluble selectin levels in patients with rheumatoid arthritis and systemic sclerosis. Scand J Immunol 2004;59:315-20.

[76] Wallberg-Jonsson S, Cvetkovic JT, Sundqvist KG, Lefvert AK, RantapaaDahlqvist S. Activation of the immune system and inflammatory activity in relation to markers of atherothrombotic disease and atherosclerosis in rheumatoid arthritis. J Rheumatol 2002;29:875-82.

[77] Daza L, Aguirre M, Jimenez M, Herrera R, Bollain JJ. Common carotid intimamedia thickness and von Willebrand factor serum levels in rheumatoid arthritis female patients without cardiovascular risk factors. Clin Rheumatol 2007;26:533-7.

[78] Ingegnoli F, Fantini F, Favalli EG, Soldi A, Griffini S, Galbiati V, et al. Inflammatory and prothrombotic biomarkers in patients with rheumatoid arthritis: effects of tumor necrosis factor- $\alpha$ blockade. J Autoimmun 2008;31: 175-9.

[79] Maki-Petaja KM, Cheriyan J, Booth AD, Hall FC, Brown J, Wallace SM, et al. Inducible nitric oxide synthase activity is increased in patients with rheumatoid arthritis and contributes to endothelial dysfunction. Int I Cardiol 2008;129:399-405.

[80] Sari I, Okan T, Akar S, Cece H, Altay C, Secil M, et al. Impaired endothelial function in patients with ankylosing spondylitis. Rheumatology 2006;45: 283-6.

[81] Taylan A, Sari I, Kozaci DL, Yildiz Y, Bilge S, Coker I, et al. Evaluation of various endothelial biomarkers in ankylosing spondylitis. Clin Rheumatol 2012;31: 23-8.

[82] Jonsson SW, Backman C, Johnson O, Karp K, Lundstrom E, Sundqvist KG, et al. Increased prevalence of atherosclerosis in patients with medium term rheumatoid arthritis. J Rheumatol 2001;28:2597-602.

[83] Bresnihan B, Roux-Lombard P, Murphy E, Kane D, FitzGerald O, Dayer JM. Serum interleukin 18 and interleukin 18 binding protein in rheumatoid arthritis. Ann Rheum Dis 2002:61:726-9.

[84] Bodnar N, Kerekes G, Seres I, Paragh G, Kappelmayer J, Nemethne ZG, et al. Assessment of subclinical vascular disease associated with ankylosing spondylitis. J Rheumatol 2011;38:723-9.

[85] Irace C, Mancuso G, Fiaschi E, Madia A, Sesti G, Gnasso A. Effect of anti TNF- $\alpha$ therapy on arterial diameter and wall shear stress and HDL cholesterol. Atherosclerosis 2004; 177:113-8.

[86] Galarraga B, Khan F, Kumar P, Pullar T, Belch JJ. C-reactive protein: the underlying cause of microvascular dysfunction in rheumatoid arthritis. Rheumatology 2008;47:1780-4.

[87] Sandoo A, Carroll D, Metsios GS, Kitas GD, Veldhuijzen van Zanten IJ. The association between microvascular and macrovascular endothelial function in patients with rheumatoid arthritis: a cross-sectional study. Arthritis Res Ther 2011;13:R99.

[88] van Eijk IC, Peters MJ, Serne EH, van der Horst-Bruinsma IE, Dijkmans BA, Smulders YM, et al. Microvascular function is impaired in ankylosing spondylitis and improves after tumour necrosis factor alpha blockade. Ann Rheum Dis 2009;68:362-6.

[89] Conway EM, Nowakowski B. Biologically active thrombomodulin is synthesized by adherent synovial fluid cells and is elevated in synovial fluid of patients with rheumatoid arthritis. Blood 1993;81:726-33.

[90] Veale DJ, Maple C, Kirk G, McLaren M, Belch JJ. Soluble cell adhesion molecules: P-selectin and ICAM-1, and disease activity in patients receiving sulphasalazine for active rheumatoid arthritis. Scand J Rheumatol 1998;27: 296-9.

[91] McEntegart A, Capell HA, Creran D, Rumley A, Woodward M, Lowe GD. Cardiovascular risk factors, including thrombotic variables, in a population with rheumatoid arthritis. Rheumatology 2001;40:640-4.

[92] Undas A, Gissel M, Kwasny-Krochin B, Gluszko P, Mann KG, Brummel-Ziedins KE. Thrombin generation in rheumatoid arthritis: dependence on plasma factor composition. Thromb Haemost 2010;104:224-30.

[93] Lau CS, McLaren M, Hanslip J, Kerr M, Belch JJ. Abnormal plasma fibrinolysis in patients with rheumatoid arthritis and impaired endothelial fibrinolytic response in those complicated by vasculitis. Ann Rheum Dis 1993;52:643-9.

[94] Wendling D, Racadot E. Serum tissue factor levels correlate with inflammation in ankylosing spondylitis. Joint Bone Spine 2006;73:403-5.

[95] Prati C, Racadot E, Cedoz JP, Toussirot E, Wendling D. Thrombin generation in rheumatoid arthritis. Joint Bone Spine 2012;79:522-3.

[96] Prati C, Racadot E, Cedoz JP, Wendling D. Thrombin generation in ankylosing spondylitis. Clin Rheumatol 2011;30:511-4.

[97] Jin T, Tarkowski A, Carmeliet P, Bokarewa M. Urokinase, a constitutive component of the inflamed synovial fluid, induces arthritis. Arthritis Res Ther 2003;5:R9-17.

[98] Farrell AJ, Williams RB, Stevens CR, Lawrie AS, Cox NL, Blake DR. Exercise induced release of von Willebrand factor: evidence for hypoxic reperfusion microvascular injury in rheumatoid arthritis. Ann Rheum Dis 1992;51: $1117-22$.

[99] Cobankara V, Ozatli D, Kiraz S, Ozturk MA, Ertenli I, Turk T, et al. Successfu treatment of rheumatoid arthritis is associated with a reduction in serum sE-selectin and thrombomodulin level. Clin Rheumatol 2004;23:430-4.

[100] Gasparyan AY, Sandoo A, Stavropoulos-Kalinoglou A, Kitas GD. Mean platelet volume in patients with rheumatoid arthritis: the effect of anti-TNF- $\alpha$ therapy. Rheumatol Int 2010;30:1125-9.

[101] Charles P, Elliott MJ, Davis D, Potter A, Kalden JR, Antoni C, et al. Regulation of cytokines, cytokine inhibitors, and acute-phase proteins following anti-TNF- $\alpha$ therapy in rheumatoid arthritis. J Immunol 1999;163:1521-8.

[102] Hurlimann D, Forster A, Noll G, Enseleit F, Chenevard R, Distler O, et al. Antitumor necrosis factor-a treatment improves endothelial function in patients with rheumatoid arthritis. Circulation 2002;106:2184-7.

[103] Gonzalez-Juanatey C, Testa A, Garcia-Castelo A, Garcia-Porrua C, Llorca J Gonzalez-Gay MA. Active but transient improvement of endothelial function in rheumatoid arthritis patients undergoing long-term treatment with antitumor necrosis factor alpha antibody. Arthritis Rheum 2004;51:447-50.

[104] Bilsborough W, Keen H, Taylor A, O'Driscoll GJ, Arnolda L, Green DJ. Antitumour necrosis factor- $\alpha$ therapy over conventional therapy improves endothelial function in adults with rheumatoid arthritis. Rheumatol Int 2006;26:1125-31.

[105] Bosello S, Santoliquido A, Zoli A, Di Campli C, Flore R, Tondi P, et al. TNFblockade induces a reversible but transient effect on endothelial dysfunction in patients with long-standing severe rheumatoid arthritis. Clin Rheumatol 2008:27:833-9. 